DOI https://doi.org/10.30525/978-9934-588-91-4-4

\title{
ФЕНОМЕН КРИЗИ: ПОГЛЯД 3 ПОЗИЦІЙ ФІЛОСОФІЇ
}

\author{
Павлов В. Л. \\ кандидат філософських наук, \\ доиент кафедри гуманітарних дисциплін \\ Національного університету харчових технологій \\ м. Київ, Украӥна
}

Савельєва М. Ю.

доктор філософських наук, професор

Центру гуманітарної освіти Національної академії наук України м. Київ, Украӥна

Суходуб Т. Д. кандидат філософських наук, дочент Центру гуманітарної освіти Національна академія наук Украӥни м. Київ, Украӥна

Термін «криза» не часто вживається у буденному спілкуванні людей, філософській та соціологічній літературі. Впродовж довгого часу він не мав статусу належним чином обгрунтованого наукового поняття. Хоча саме явище, для позначення якого використовується дане слово, не таке вже й рідке в житті індивідів, їх різноманітних спільностей, суспільства в цілому. Кризи час від часу з більшою або меншою мірою заявляють про себе в природі, науці, сімейних відносинах, художній творчості. 3 особливою силою проявляються в економіці, політиці, сферах управління, фінансів та банківської діяльності.

Кризові явища мають складну природу, в якій внутрішньо взаємодіють чинники об'єктивного і суб'єктивного характеру, необхідність і випадковість, внутрішне і зовнішне, матеріальне i нематеріальне, загальне і одиничне. Вирізняючись у кожному конкретному випадку неповторною особливістю в контексті змісту та форми, часу протікання, масштабу, наслідків, криза завжди залишається кризою, тобто зберігає певні загальні риси, властиві саме даному стану подій. Сутнісною ознакою кризи виступає вичерпаність можливостей функиіонування системи на основі апробованих засад. Криза виникає тоді, коли певна система (індивід, колектив, пізнавальна чи світоглядна парадигма, соціальний інститут, сфера природи тощо) демонструє неможливість продуктивно функціонувати, використовуючи свій традиційний потенціал. Це ситуація, в якій все, що забезпечувало об'єкту безболісний розвиток, не тільки перестає приносити бажані результати, а й деструк- 
тивно впливає на нього, робить нездатним до сходження на новий, більш високий ступінь. В період кризи загострюються суперечності, навіть ті, що існували у прихованому виді; $з$ усією силою проявляються слабкі сторони об'єкта. Якщо йдеться про системи, які функціонують завдяки активності людей, криза безжалісно «оголює» недоліки і переваги кожного, жорстко «відсікає» все старе, віджиле і водночас створює благодатні умови для генерації нових ідей та підходів, прояву творчого мислення, продукування нестандартних пропозицій.

Хоча кризи - невід'ємна складова людства впродовж всієї його історії, предметом спеціального осмислення стали не так давно. Не в останню чергу пов'язано це зі станом страху, який супроводжує будьяку кризу. Адже вона - розрив поступовості, часто втрата суб'єктом віри в себе, в інших людей, в силу соціальних інститутів тощо. Це крах надій, руйнування впевненості у стабільності логіки розвитку дійсності, непорушності базових устоїв життя. Кризи довгий час асоціювались лише з руйнуванням звичного, усталеного, стабільного, непорушного. Сприймали їх як відхилення від нормального (правильного) ходу речей, нерідко як кару за свої гріхи. До того ж, ці явища, як правило, паралізують волю індивідів, позбавляють багатьох здатності не тільки шукати вихід з ситуації, що склалась, а й адекватно оцінювати довкілля.

Поступово в соціумі прийшло усвідомлення необхідності осмислення кризи як хоч i незвичного, «неприємного», значною мірою аномального прояву дійсності, та все ж іiі складової. Більше того, в кризі почали шукати позитивні моменти, використання яких дозволяє вийти за межі традиційності, усталеності в бутті людей. Складався i відповідний понятійний апарат, за допомогою якого представники різних форм знання описували формування і функціонування криз. Як наслідок, виокремились окрема сфера знань («кризологія»), змістовне поле якої - криза у всій різноманітності прояву цього явища - та нова професія - кризовий менеджер.

Одним $з$ перших, хто намагався осмислити кризу на рівні філософських узагальнень, був яскравий представник французького Просвітництва XVIII ст. Ж.-Ж. Руссо. Констатував невідповідність сучасних йому соціальних інститутів, органів державного управління економічним, політичним, духовним процесам, що відбувались в той період у Франції та в інших країнах Свропи. Вбачав у означеній невідповідності основу виникнення майбутньої кризи, яка 3 усією силою заявить про себе у кінці XVIII ст. і приведе до могутніх соціальних трансформацій, що змінять підвалини всього європейського соціуму.

Виникнення і функціонування марксизму, особливо в його економічному та соціальному проявах. значною мірою також пов'язане 3 аналізом кризових явищ в економіці, політиці, соціальній сфері низки європейських держав. I хоча сам термін «криза» використовується тут 
зрідка, самі кризові процеси стали предметом детального аналізу в працях К. Маркса та Ф. Енгельса. Спеціально варто назвати у цьому плані роботу Ф. Енгельса «Положення робітничого класу в Англії» та роботу К. Маркса «Капітал». Блискучий аналіз еволюції криз в капіталістичному суспільстві представлений у праці В. Леніна «Імперіалізм як вища стадія капіталізму», а в його роботі «Матеріалізм і емпіріокритицизм» детально досліджена криза у фізиці на рубежі XIX-XX ст. та накреслені шляхи її подолання.

Саме в цей час у філософії і науці починають формуватись базові теоретико-методологічні засади дослідження кризовості як особливого стану об’єктивної та суб'єктивної реальності. Велика заслуга в цьому належить німецькому філософу кінця XIX - першої третини $\mathrm{XX}$ ст. Е. Гуссерлю. Запропонований ним герменевтикофеноменологічний метод став наріжним каменем продуктивної методології пізнання дійсності, криз у тому числі. Апелюючи не до конкретних кризових явищ, а до кризи як специфічного феномену, він робить висновок, що причина цього утворення - у зневірі людей в силі раціональності. В центрі уваги теоретика - зміна статусу наукового знання в свідомості та житті індивідів і суспільства в цілому. На його думку, традиційна, звична, апробована століттями раціональність вичерпала себе. Вона продукує «кризову свідомість», яка, в свою чергу, викликає до життя різноманітні кризи, 3 якими не здатна справитись. Тому потрібна нова, інша раціональність - більш високого рівня та продуктивності. Праці Е. Гуссерля «Криза європейського людства і філософія» та «Криза європейських наук і трансцендентальна феноменологія» пронизані цією ідеєю.

На жаль, побажання мислителя не були прийняті до уваги ні його сучасниками, ні нащадками. Те, що Е. Гуссерль називав «кризовістю свідомості» трансформувалось 3 часом у «кризовість культури». У XX ст. 3'явилась низка термінів, за допомогою яких фахівці почали позначати різні кризові явища у суспільстві: «людина маси» (Х. Ортегаi-Гассет, Е. Муньє), стан «безпритульності» (М. Бубер), технократизм існування (Л. Мамфорд), стан відчаю, страху і тривоги (П. Тілліх), «негуманна» людина i «неприродна» природа (Р. Гвардіні) та ін. Так популярний у XX ст. філософський напрям екзистенціалізм сформувався та існує до сьогоднішнього дня не в останню чергу саме завдяки осмисленню кризових явищ в житті індивідів, їх різноманітних спільностей, суспільства в цілому. Значний внесок у розробку проблеми кризи вніс французький філософ ХХ ст. П. Рікьор.

По мірі накопичення знань про кризу у філософській, соціологічній та іншій літературі з'явились нові терміни, які дозволяють фіксувати процеси, що мають безпосереднє відношення до даного явища. Передусім йдеться по поняття «ризик», «катастрофа», «колапс». Ризик - це подія, явище, дія, що передують кризі і впливають на іiі 
виникнення. Катастрофа - результат кризи. Термін «колапс» використовують нерідко як синонім терміну «катастрофа» або ж для позначення неконтрольованого розвитку подій, наслідком якого стає знищення конкретного об'єкта (системи). Катастрофа і колапс - у вищій мірі негативні, руйнівні результати кризи, яку не вдалось вчасно і продуктивно подолати. На думку німецького філософа О. Шпенглера, «всесвітня історія... рухається від катастрофи до катастрофи...» [2, с. 190].

Багато уваги феномену ризику приділив у $80-\mathrm{x}$ роках минулого століття німецький соціолог У. Бек. Вважав, що ризиками «...нас наділяє... сам розвиток цивілізації» [1, с. 26], а індустріальне суспільство 3 його гонитвою за технічним вдосконаленням та прибутком створює ситуації у різних сферах життя, які можуть продукувати в них незворотні процеси, котрі здатні у більш чи менш віддаленій перспективі привести до самознищення цивілізації. Ризик у масових масштабах своїм результатом 3 необхідністю буде мати «суспільство ризику». Ризик утримує в собі небезпеку для того, хто втягнутий в його силове поле. Правда, ця небезпека має потенційний характер, характер можливості, яка не завжди переходить у дійсність. Багато ризиків заявляють про себе спочатку не відкрито. Вони приховані від свідомості людей. До того ж, не завжди піддаються емпіричній верифікації.

В сучасних умовах все голосніше звучить думка, що при всій важливості накопичених людством знань про кризи, вони в повній мірі не відповідають нинішнім реаліям кризових ситуацій. Кризи залишились кризами, при цьому стали принципово іншими: за змістом, протяжністю, масштабом, непередбаченістю, катастрофічністю наслідків та іншими характеристиками. Фахівці вважають, що рубіж XX-XXI ст. - час становлення нового історичного періоду: періоду «світового суспільства ризику» (використовується також термін «ера криз»). Причин для такого висновку більш, ніж достатньо: періодичні кризи в економіці, що мають не тільки локальний, а й глобальний характер; могутні кризи в банківській сфері; кризові явища в міжнародній політиці, пов'язані з свідомим ігноруванням норм міжнародного права; екологічні потрясіння і катастрофи; масові епідемії тощо. Все це потребує принципово нових підходів і трактувань, в тому числі на рівні філософії.

\section{Лiтература:}

1. Бек У. Общество риска. На пути к другому модерну / Пер. с нем. В. Седельника и Н. Федоровой; Послесл. А. Филиппова. М.: Прогресс-Традиция, 2000, 384 с.

2. Геде А. Философия кризиса / Пер. с венгер. / Общ. ред. и послесл. Б. Н. Бессонова. М.: Прогресс, 1978. 374 с. 